\title{
KLASIFIKASI EMOSI YANG TERDAPAT DALAM LIRIK LAGU FOURTWNTY ALBUM FUNGSI EGO DAN OTAK
}

\author{
Endang Sulistyowati ${ }^{1}$, Noor Indah Wulandari ${ }^{2}$, AshifaDinda Putri ${ }^{3}$ \\ STKIP PGRI Banjarmasin ${ }^{1,2}$ \\ Jalan Sultan Adam Komplek H. Iyus, No. 18 RT. 23 Banjarmasin, \\ Kalimantan Selatan, Kode pos 70121 \\ email: endangsulistyowati56@gmail.com dan noorindahbjm@gmail.com
}

Dinas Pendidikan Kab.Banjar ${ }^{3}$

Jl. Pendidikan No. 7 Sungai Ulin Kec.Banjarbaru Kalimantan Selatan. Kodepos: 70614

email: ashifadindaputri@gmail.com

\section{ABSTRAK}

Sastra tidak saja dinilai sebagai sebuah karya seni yang memiliki budi, imajinasi, dan emosi, tetap telah dianggap sebagai suatu karya kreatif yang dimanfaatkan sebagai konsumsi intektual disamping konsumsi emosi. Penelitian ini berfokus pada lirik lagu Fourtwnty album fungsi Ego dan Otak.

Penelitian ini bertujuan untuk: (1) mengklasifikasikan emosi yang terdapat dalam lagu Fourtwnty album Fungsi Ego dan Otak.(2) mendeskripsikan gambaran emosi yang terdapat dalam lagu Fourtwnty album Fungsi Ego dan Otak.(3) mendeskripsikan konflik batin yang terdapat dalam lagu Fourtwnty album Fungsi Ego dan Otak.

Pendekatan penelitian menggunakan pragmatik sastra, dengan jenis penelitian kepustakaan. Penelitian ini menggunakan metode dekriptif kualitatif, dengan sumber data dari album yang berjudul Fourtwnty - Ego \& Fungsi Otak (Full Album 2018).Teknik pengumpulan data dalam penelitian ini adalah teknik eksplorasi.Pada teknik analisis data menggunakan metode deskriptif analisis. Metode deskriptif analisis yaitu dalam sebuah penelitian dilakukan tahap pendeskripsian terhadap fakta-fakta yang terdapat pada novel, yang kemudian dilanjutkan dengan melakukan analisis terhadap fakta yang diperoleh.

Hasil penelitian diperoleh bahhwa: (1) Klasifikasi emosi yang tersaji pada lirik lagu bersinggungan tentang rasa bersalah, menghukum diri sendiri, rasa malu, kesedihan, kebencian, Dan cinta. Gambaran emosi yang tersaji berkaitan tentang id, ego, Dan superego pada lagu Fourtwnty meliputi beberapa hal: seperti prinsip kesenangan, mencari kenikmatan, menghindari ketidaknyamanan, realitas/kenyataan pada diri, refleksi internalisasi aturan budaya Dan moral. (3) Konflik batin yang terjadi dalam diri penyair beserta lagunya mencakup dendam, marah, kecewa, sedih, takut, Dan bingung.

Kata Kunci: emosi, fungsi ego, fungsi otak

\section{PENDAHULUAN}

Dalam kehidupan sehari-hari, manusia tidak pernah lepas dengan permasalahan di lingkungan sekitarnya. Berbagai permasalahan tersebut tidak selamanya stabil,ada kalanya menyimpang dan jauh dari aturan yang diterapkan oleh masyarakat dan seringkali menimbulkan sebuah konflik. Konflik permasalahan tersebut kadang bisa tergambar dari sebuah seni yang disebut dengan sastra. 
Lirik lagu merupakan ekspresi seseorang tentang suatu hal yang sudah dilihat, didengar maupun dialaminya. Dalam mengekspresikan pengalamannya, penyair atau pencipta lagu melakukan permainan kata-kata dan bahasa untuk menciptakan daya tarik dan kekhasan terhadap lirik atau syairnya. Permainan bahasa ini dapat berupa permainan vokal, gaya bahasa maupun penyimpangan makna kata dan diperkuat dengan penggunaan melodi dan notasi musik yang disesuaikan dengan lirik lagunya sehingga pendengar semakin terbawa dengan apa yang dipikirkan pengarangnya.

Klasifikasi emosi adalah hal yang membahasa tentang apa saja emosi yang terkandung dalam diri seseorang. Seperti halnya kegembiraan, kemarahan, ketakutan, kesedihan, kebencian. Situasi yang demikian membangkitkan perasaan-perasaan tersebut sangat terkait dengan tindakan yang ditimbulkan dan berakibat meningkat ketegangan dalam diri seseorang. Sejalan yang disampaikan oleh Minderop (2013:39) kegembiraan, kemarahan, ketakutan, dan kesedihan kerap kali dianggap sebagai emosi yang paling mendasar (primary emotions). Situasi yang membangkitkan perasaanperasaan tersebut sangat terkait dengan tindakan yang ditimbulkannya dan mengakibatkan meningkat ketegangan.

Fourtwnty adalah salah satu grup band Indie yang berdomisili di Jakarta, yang beranggotakan Ari, Nuwi dan Roots berhasil memanjakan pendengarnya dengan nada-nada santai dan nyaman didengar di seluruh Indonesia. Mereka adalah musisi multiinstrumentalis yang mendedikasikan dirinya untuk menyebarkan pesan toleransi melalui musik dan konsep yang matang.

Dipilihnya Ego \& Fungi Otak sebagai album kedua Fourtwnty ini juga melalui proses panjang. Banyak terjadi perang ego antar personel saat pembuatan album dikarenakan setiap personel jadi berubah penguasaan karakter dalam memainkan musik. Tetapi semua masalah dapat teratasi dan berakhir tetap seperti karakter Fourtwnty.

Berbicara tentang kumpulan lirik lagu terbaik Fourtwnty salah contoh karya mereka yaitu Kita Pasti Tua, lirik lagu tersebut memiliki makna yang menggambarkan tentang kehidupan manusia di masa mendatang, lirik lagu ini membuat kita terbayang masa tua yang nantinya terjadi perubahan hidup, dari wajah sampai rambut mulai beruban. Lirik lagu Kita Pasti Tua didominasi musik yang bernuansa pelan, lagu tersebut bukanlah lagu yang bermuatan pesimis. Lagu ini justru mengajak banyak orang tetap punya semangat layaknya masih muda, meski di usia yang sudah tua atau tidak muda lagi.

Indie atau yang biasa disebut karya music bebas bukanlah suatu genre musik, melainkan sebuah gerakan musik yang bebas dan mandiri. Band Indie cenderung menciptakan lagu sesuai 
dengan apa yang mereka sukai dan genre yang mereka inginkan. Secara singkat Indie adalah singkatan dari kata independent, yaitu sifat-sifat yang mandiri, bebas dan merdeka. Dalam dunia musik, indie berarti melakukan Do-it-Yourself approach saat melakukan rekaman dan publishing, band indie tidak seperti band popular atau band di arus utama yang terikatdengan label rekaman, mulai pemilhan rekaman lagu sampai promosi mereka melakukannya sendiri.

\section{METODE}

Pendekatan yang digunakan dalam penelitian adalah pendekatan pragmatik sastra yang ditinjau dari bentuk pragmatik sastra yang penelitian pada aspek kegunaan. Pendekatan ini muncul atas dasar ketidakpuasan terhadap penelitian struktural murni yang hanya memandang karya sastra sebagai teks saja. Jenis kajian ini mengeksplorasi bagaimana banyak sekali hal-hal yang tidak dikatakan oleh penutur dapat diketahui sebagai bagian dari apa yang dikomunikasikan. Pragmatik adalah kajian tentang bagaimana orang-orang tahu lebih banyak hal yang dikomunikasikan daripada yang dikatakan (Yule, 2006:9).

Untuk mendukung penelitian ini peneliti juga menggunakan jenis penelitian kepustakaan karena berdasarkan karya tulis. Salah satu jenis penelitian bila dilihat dari tempat pengambilan data adalah penelitian kepustakaan.

Harahap (2014:68) mengatakan sebuah penelitian dikatakan kepustakaan karena data-data atau bahan-bahan yang diperlukan dalam menyelesaikan penelitian tersebut berasal dari perpustakaan baik berupa buku, ensklopedi, kamus, jurnal, dokumen, majalah dan lain sebagainya. Untuk memudahkan dalam penelitan kepustakaan tentunya seorang peniliti dituntut untuk mengenal dan memahami organisasi dan tata kerja perpustakaan. Hal ini adalah penting agar lebih mudah memperoleh dan mengakses bahan-bahan atau sumber-sumber yang dibutuhkan.

Teknik pengumpulan data dalam penelitian ini adalah teknik eksplorasi. Teknik eksplorasi adalah bertujuan untuk menggali informasi secara mendalam atau detail dari lirik lagu Fourtwnty dalam album Fungsi Ego dan Otak.

\section{HASIL DAN PEMBAHASAN}

\section{Klasifikasi Emosi yang terdapat dalam Lirik Lagu Fourtwnty Album Fungsi Ego Dan Otak}

Emosi adalah perasaan yang dimiliki setiap manusia, dan tentunya memiliki peran penting dalam kehidupan setiap manusia. Emosi di klasifikasikan menjadi 6 subtansi yang meliputi: a) rasa bersalah b) menghukum diri sendiri c) rasa malu d) kesedihan e) kebencian f) cinta. Emosi merupakan suatu keadaan yang menggambarkan apa yang sedang dirasakan oleh seseorang ketika 
terjadi perubahan yang ia rasakan. Emosi tentunya akan berpengaruh dan pastinya akan terlibat dalam setiap aktivitas yang dilakukan oleh individu setiap harinya.

Berikut paparan lirik lagu Fourtwnty Segelas Berdua Album Fungsi Ego dan Otak:

Waktu itu aku bertamu

Menunggu dikursi kayu ibumu

Kembang lili tak tahu malu

Berada di genggam tangan kananku

Merayu bukan gayaku

Romansa ku berbeda

Segelas berdua berwarna merah isi dan langitnya

Dibawah aroma hamparan hijau

Kembang lili tak tahu malu

Berada di genggam tangan kananku

Merayu bukan gayaku

Romansa ku berbeda

Segelas berdua berwarna merah isi dan langitnya

Dibawah aroma hamparan hijau

Segelas berdua berwarna merah isi dan langitnya

Dibawah aroma hamparan hijau

Hijau

Hamparan hijau

Hamparan hijau

Hamparan hijau

Makna umum lagu Segelas Berdua murni berbicara tentang cinta dan rasa malu, karena hal yang digambarkan oleh seorang penyairnya hanya cinta dan kebahagiaan bersama seseorang terkasih. Juga rasa malu terhadap kekasihnya saat bertemu. Seperti larik yang disampaikan diatas tidak ada sedikitpun emosi yang berjenis rasa bersalah, menghukum sendiri, kesedihan dan kebencian.

\section{Rasa Malu}

Rasa malu adalah salah satu bentuk emosi manusia. Malu memiliki arti beragam, yaitu sebuah emosi, pengertian, pernyataan, atau kondisi yang dialami manusia akibat sebuah tindakan yang dilakukannya sebelumnya, dan kemudian ingin ditutupinya.

\section{Kutipan 1}

"menunggu dikursi kaya ibumu

kembang lili tak tau malu

berada di genggam tangan kananku" 
Berdasarkan kutipan 1 sang penyair berusaha mendeskripsikan sebuah tindakan romantisnya dalam bentuk kesederhanaan. “kembang lili tak tau malu, berada di genggam tangan kananku”. Dalam lirik ini terdapat sebuah perumpamaan yang luas, yaitu “kembang lily”. Jika kita telaah secara gamblang, kembang lili adalah sebuah bunga. Namun bunga yang digambarkan dalam bentuk lain. Bisa berupa cincin atau benda lainnya.

\section{Cinta}

Cinta adalah sebuah emosi dari kasih sayang yang kuat dan ketertarikan pribadi. Dalam konteks filosofi cinta merupakan sifat baik yang mewarisi semua kebaikan, perasaan belas kasih dan kasih sayang.

\section{Kutipan 2}

"Segelas berdua berwarna merah isi dan langitnya

Dibawah aroma hamparan hijau"

Berdasarkan kutipan dua lagu tersebut bagian intisari lagu (reff) terdapat sebuah perumpamaan yang sering membuat kita bertanya-tanya tentang makna dari lirik "segelas berdua berwarna merah isi dan langitnya, dibawah aroma hamparan hijau”. Memang penggunaan metafora dalam lagu merupakan hak penyair lagu mengekspresikan perasaanya, hal tersebut juga terlihat pada lagu ini. Jika mengulas lebih dalam mengenai diksi yang digunakan oleh penyair maka makna dari lirik "segelas berdua berwarna merah isi dan langitnya, dibawah aroma hamparan hijau” adalah sebagai berikut.

Pertama: "segelas berdua berwarna merah isi dan langitnya" gelas disini merupakan perumpamaan yang pada dasarnya merupakan wadah atau tempat untuk mencurahkan sesuatu. Dalam konteks lagu ini "Segelas Berdua" memiliki perumpamaan dua orang insan yang mencurahkan perasaannya dalam sebuah ikatan janji. Sementara maksud dari lirik "berwarna merah isi dan langitnya" adalah perumpamaan sinestesia dengan menggunakan warna merah untuk mendeskripsikan suasana hati yang saling merekah layaknya bunga mawar berwarna merah, indah dan wangi

\section{Sedih}

Sedih adalah suatu emosi yang ditandai oleh perasaan tidak beruntung, kehilangan, dan ketidakberdayaan. Saat sedih manusia sering menjadi lebih diam, kurang bersemangat dan menarik diri. Kesedihan adalah lawan dari kebahagiaan atau kegembiraan dan serupa dengan dukacita atau kesengsaraan. 


\section{Kutipan 3}

"tolong jauhkan nafsuku

Dari pesona hawamu

aku terjangkit dan sakit

terjebak di ruang sempit"

Lirik tersebut menggambarkan sebuah ketergantungan terhadap sesuatu ataupun seseorang, dari bait pertama dipaparkan sebuah kalimat "tolong jauhkan nafsuku dari pesona hawamu". Makna nafsu di sini merupakan sebuah keinginan yang menggebu terhadap sesuatu ataupun seseorang, bagaikan sebuah candu yang berkali-kali ingin mengonsumsinya semisal tatapan, atau hanya sekedar mendengarkan suaranya. Saat tak bisa mewujudkan harapan tersebut tentunya akan merasa seperti terjebak dalam ruangan sempit, pengap dan terpapar oleh sakitnya merindu.

\section{Menghukum Diri Sendiri}

Perasaan bersalah yang mengganggu adalah sebagaimana terdapat dalam sikap menghukum diri sendiri si individu terlihat sebagai sumber dari sikap rasa bersalah. Rasa bersalah tipe ini memiliki implikasi terhadap berkembangnya gangguan-gangguan kepribadian yang terkait dengan kepribadian, penyakit, mental dan psikoterapi.

\section{Kutipan 4}

"kelopak mataku lelah menjabarkan arti melayang"

"Melanda redup tantrumku"

Makna lirik yang berbunyi "kelopak mataku lelah menjabarkan arti melayang” menjelaskan sebuah keadaan dimana ia mencoba melarikan diri dari masalah dunia melalui hal yang salah dengan cara ngefly (melayang). Ia melampiaskan diri dengan cara yang salah, sehingga menyebabkan sebuah keadaan ledakan emosi yang menerpa kedamaian. Hal tersebut dijabarkan melalui lirik "melanda redup tantrumku”. Merujuk dari wikipedia, Tantrum memiliki arti sebuah ledakan emosi.

\section{Rasa Bersalah}

Rasa bersalah bisa disebabkam oleh adanya konflik antara express impuls dan standar moral (impuls expression versus moral standar. Semua kelompok masyarakat secara kultural memiliki peraturan untuk mengendalikan impuls yang diawali dengan pendidikan semenjak masa kanakkanak hingga dewasa, termasuk pengendalian nafsu seks. Seks dan agresi merupakan dua wilayah yang selalu menimbulkan konflik yang dihadapkan pada standar moral. Pelanggaran terhadap standar moral inilah yang menimbulkan rasa bersalah. 


\section{Kutipan 5}

"ini bukan cerita langka tak sedikit orang melakukannya menggambar tubuhnya"

Kehadiran tatto memang bukan hal yang tabu di masyarakat era moderen khususnya indonesia kini. Walau pada era ordebaru stigma tentng orang yang memakai tatto adalah penjahat, namun hal tersebut tetap saja bukan hal yang tabu dan langka. Sisi unik dalam lagu Realita memunculkan emosi cinta yang terkesan berlebihan. Jenis emosi cinta dalam pengertian dewasa ini, ialah menunjukkan hal tentang ambisi anak muda yang terkesan berlebihan dalam memanfaatkan masa muda.

\section{Kebencian}

Kebencian atau perasaan benci (hate) berhubungan erat dengan perasaan marah, cemburu dan iri hati. Ciri khas yang menandai perasaan benci adalah timbulnya nafsu atau keinginan untuk menghancurkan objek yang menjadi sasaran kebencian. Perasaan benci bukan sekedar timbulnya perasaan tidak suka atau aversi/enggan yang dampaknya ingin menghindar dan tidak bermaksud menghancurkan. Sebaliknya perasaan benci selalu melekat di dalam diri seseorang dam ia tidak akan pernah merasa puas sebelum menghancurkannya; bila objek tersebut hancur ia akan merasa puas.

\section{Kutipan 6}

"dan langit memerah

Semesta pun marah

Bumiku berdarah"

"meradang egoku

meradang tangisku

menghadang tawamu

meradang egoku

meradang tangisku

menghalang tawamu

meradang egoku

meradang tangisku

menghalang tawamu"

"maafkan ini karenaku

biang masalah masa lalu

bertemu faham - faham itu

simpang siur kini namaku"

Klasifikasi emosi yang tersaji pada lirik lagu Trilogi beragam, mulai dari rasa kesedihan, kebencian, dan cinta. Rasa kebencian menunjukkan kepada seseorang yang melakukan vandalisme, 
sedangkan rasa kesedihannya menunjukkan tentang carut-marutnya lingkungan sekitar. Hal berbeda tersaji pada emosi rasa cinta penyair tetap berharap keburukan yang terjadi entah itu terhadap satu individu maupun lingkungan dapat bisa berubah dan sadar.

\section{Gambaran Emosi yang terdapat dalam Lirik Lagu Fourtwnty Album Fungsi Ego dan Otak}

Gambaran emosi meliputi Id, Ego, dan Superego. Gambaran emosi merupakan suatu keadaan yang menggambarkan apa yang sedang dirasakan oleh seseorang ketika terjadi perubahan yang ia rasakan. Emosi tentunya akan berpengaruh dan pastinya akan terlibat dalam setiap aktivitas yang dilakukan oleh individu setiap harinya.

\section{Superego (Refleksi Internalisasi Aturan Budaya dan Moral)}

Superego adalah hati nurani, jadi superego memberikan pedoman untuk membuat penilaian, baik yang benar atau yang salah. Superego hadir dalam sadar, prasadar dan tidak sadar. Id, Ego Dan Superego saling mempengaruhi satu sama lain, ego bersama dengan superego mengatur dan mengarahkan pemenuhan id dengan berdasarkan aturan-aturan yang benar dalam masyarakat, agama dan perilaku yang baik atau buruk.

\section{Kutipan 7}

"segelas berdua berwarna merah isi dan langitnya dibawah aroma hamparan hijau"

Pada bait ketiga penyair tetap mempertahankan gambaran emosi, mencari kenikmatan namun juga disisipi refleksi internalisasi budaya dan moral. Menurut pandangan penulis hal tersebut dilakukan penulis karena dalam keadaan sedang bahagia seperti pada bait ketiga yang tersaji pada berikut ini, Segelas berdua berwarna merah isi dan langitnya/Dibawah aroma hamparan hijau.

\section{Id (Menghindari Ketidaknyamanan)}

Id merupakan komponen yang hadir sejak lahir, aspek kepribadian sepenuhnya sadar dan termasuk dari perilaku naruliah dan primitive. Id juga didorong oleh prinsip kesenangan untuk kepuasan segera dari semua keinginan dan kebutuhan.

\section{Kutipan 8}

"mungkin bukanlah wujudmu ranjang ternyaman bagiku

henti bergumam hati

cabutlah biar tak kusut" 
Pada lagu Kusut penyair menggambarkan emosinya dalam menghindari ketidaknyamanan terhadap problem dan realita yang terjadi disekitarnya. Disisi lain penyair mencoba merubah atau menggeneralisasikan keadaan yang dahulunya ia tidak sukai menjadi ia sukai.

\section{Id (Menghindari Ketidaknyamanan)}

Id merupakan komponen yang hadir sejak lahir, aspek kepribadian sepenuhnya sadar dan termasuk dari perilaku naruliah dan primitive. Id juga didorong oleh prinsip kesenangan untuk kepuasan segera dari semua keinginan dan kebutuhan.

\section{Kutipan 9}

"sudah pernah hilang

sudah pernah dialam sana

sudah pernah gila

sudah pernah didalam sana"

Sebuah gambaran emosi yang tersaji pada lagu Nyanyian Surau pada bait terakir ialah tentang kesendirian seseorang dan mulai merasa absurd akan kehidupannya. Penyair menggambarkan kesunyian-kesunyian sosok tokoh yang ada pada lagu tersebut mengalami kesenjangan kepribadiannya sendiri lebih tepatnya gambaran emosi menghindari ketidaknyamanan pada dirinya.

\section{Superego (Refleksi Internalisasi Aturan Budaya dan Moral)}

Superego adalah hati nurani, jadi superego memberikan pedoman untuk membuat penilaian, baik yang benar atau yang salah. Superego hadir dalam sadar, prasadar dan tidak sadar. Id, Ego Dan Superego saling mempengaruhi satu sama lain, ego bersama dengan superego mengatur dan mengarahkan pemenuhan id dengan berdasarkan aturan-aturan yang benar dalam masyarakat, agama dan perilaku yang baik atau buruk.

\section{Kutipan 10}

"ini darah muda

ini darah muda

memang tak mudah menaklukannya

ini darah muda

ini darah muda

tolong tunjuk tangan

siapa yang pernah mencoba"

Gambaran emosi yang tersaji pada lagu Realita murni berbicara tentang kebebasan dan keleluasaan yang terjadi pada anak muda. Penyair menggambarkan anak-anak muda mencoba melawan agitasi miring yang lebih tepatnya mereka mereflesikan aturan budaya dan moral. Dalam 
gambaran lain penulis menggambarkan para pemuda yang berekspresi dengan berprinsip kesenangan, mencari kenikmatan dan menghindari ketidaknyamanan.

\section{Konflik Batin yang terdapat dalam Lirik Lagu Fourtwnty Album Fungsi Ego dan Otak}

Konflik adalah suatu pertentangan atau percekcokan yang terjadi dalam diri seseorang, biasanya berbentuk seperti adanya tekanan yang terjadi dari luar.Konflik batin atau bisa juga yang disebut gejolak perasaan adalah situasi dimana antara emosi dan realita saling beradu Konflik batin meliputi 6 subtansi yakni: a) Dendam, b) Marah, c) Kecewa, d) Sedih, e) Takut, f) Bingung.

\section{Takut}

Takut adalah suatu mekanisme pertahanan hidup dasar yang terjadi sebagai respons terhadap stimulus tertentu,seperti rasa sakit atau ancaman bahaya. Takut juga merupakan salah satu dari emosi dasar selain kebahagiaan, kesedihan dan kemarahan.

\section{Kutipan 12}

"merayu bukan gayaku

romansa ku berbeda"

Pada lirik lagu di atas dapat disimpulkan bahwa penyair menggambarkan bahwa ia merasa takut untuk berbicara mesra kepada kekasihnya karena ia tidak pernah melakukan hal tersebut sebelumnya, sehingga ia merasa tidak percaya diri untuk mengungkapkan cintanya.

Untuk kutipan lagu diatas Lagu Fourtwnty Segelas Berdua juga mengalami konflik batin, namun gejolak batin atau konflik batin yang tertera pada lagu tersebut hanya bersifat sederhana. Sederhananya lagu tersebut mengalami permasalahan batin yang mana diri seseorang yang tidak biasa melakukan romantis terhadap lawan jenis namun harus bersifat romantis.

\section{Bingung}

Merasa tidak tahu arah dan tujuan yang pasti. Atau perasaan yang menitikberatkan pada ketidaktahuan dalam memutuskan atau mengambil suatu tindakan.Merasa ridak tahu arah dan tujuan yang pasti. Atau perasaan yangmenitikberatkan pada ketidaktahuan dalam memutuskan atau mengambil suatu tindakan.

\section{Kutipan 13}

"tolong jauhkan nafsuku dari pesona hawamu aku terjangkit dan sakit terjebak di ruang sempit"

Dapat disimpulkan bahwa perasaan bingung penyair rasakan terlihat pada lirik pertama dan kedua yaitu “tolong jauhkan nafsuku dari pesona hawamu” ia berharap seseorang yang menganggu 
pikirannya pergi jika terus melihat sosoknya padahal sebenarnya ia masih mengharapkan sosok tersebut dan merasa sangat sakit jika ia harus pergi dan itu tergambar pada lirik tiga dan empat, yaitu "aku terjangkit Dan sakit terjebak di ruang sempit”.

\section{Kecewa}

Perasaan yang tidak merasa puas terhadap harapan, keinginan, atau dugaan, gagal dalam usaha dan sebagainya. Kecewa adalah ungkapan rasa akibat harapan dan hasilnya tidak sama.

\section{Kutipan 14}

"membiru indraku

susah payahku melepasmu

terlihat ku palsu

tanpa rasamu menjamahku

tanpa ragamu disampingku

tanpa eratmu menggenggamku

tanpa arahmu

lagi”

Pada kutipan lagu diatas dapat disimpulkan bahwa penyair merasa kecewa dalam usahanya yang tidak bisa melepaskan seseorang yang pernah ia cintai, hal itu tergambar pada lirik satu dan dua "susah payahku melepasmu terlihat ku palsu".

Peneliti menilai lagu Kusut mengalami konflik batin antara bingung dan kecewa lantaran di lagu tersebut penyair mengalami distorsi yang berlebihan diawali oleh rasa bingung lalu meluapkannya dengan kekecewaan.

\section{Dendam}

Dendam adalah rasa marah yang tidak terlampiaskan atau tidak tersalurkan sehingga didalam hati menjadi sifat buruk yang selalu berkeinginan membalas perbuatan orang lain. Dendam merupakan sifat yang berbahaya bagi diri sendiri, keluarga maupun orang lain.

\section{Kutipan 17}

"mendengung gendang telingaku

memecah bising kala itu

terlihat jiwa - jiwa layu

terlentang didepan mataku"

Kutipan lagu di atas menggambarkan rasa kesal yang dialami oleh seseorang atas suatu kejadian yang secara langsung ia lihat sehingga menimbulkan dendam. 


\section{SIMPULAN}

Berdasarkan hasil analisis Klasifikasi Emosi Dalam Lirik Lagu Fourtwnty Album Fungsi Ego dan Otak, maka dapat disimpulkan sebagai berikut:

1. Klasifikasi emosi yang tersaji pada lirik lagu bersinggungan tentang rasa bersalah, menghukum diri sendiri, rasa malu, kesedihan, kebencian, Dan cinta.

2. Gambaran emosi yang tersaji berkaitan tentang id, ego, Dan superego pada lagu Fourtwnty meliputi beberapa hal: seperti prinsip kesenangan, mencari kenikmatan, menghindari ketidaknyamanan, realitas/kenyataan pada diri, refleksi internalisasi aturan budaya Dan moral.

3. Konflik batin yang terjadi dalam diri penyair beserta lagunya mencakup dendam, marah, kecewa, sedih, takut, dan bingung.

\section{SARAN}

1. Bagi peneliti, penelitian ini memberikan pemahaman bahwa lirik lagu bisa menjadi sumber konflik batin dari pencipta dan disampaikan kepada pendengarnya.

2. Penelitian ini juga diharapkan menjadi wawasan baru sebagai acuan dalam memahami klasifikasi emosi yang terdapat pada lagu dan dapat membantu penelitian yang sejenisnya.

3. Bagi Mahasiswa, penelitian ini diharapkan nantinya dapat dijadikan sebagai bahan untuk menambah wawasan dan memperkaya referensi khususnya bagi Mahasiswa Program Studi Pendidikan Bahasa dan Sastra Indonesia nanti kedepannya, yang sesuai dengan konsep religi dalam lirik lagu.

4. Bagi masyarakat karya tulis ilmiah ini akan menjadi bahan informasi untuk segala pembahasan dalam klasifikasi emosi pada lirik lagu Fourtwnty, yang nantinya dapat dijadikan acuan untuk mengetahui hubungan antara emosi seseorang dan lagu yang dinyanyikannya sehingga dapat menjadikan referensi dalam edukasi masa yang akan datang.

\section{DAFTAR RUJUKAN}

Afni, N. 2018. Unsur Religi dalam Lirik Lagu-lagu Sulistyowati. Skripsi tidak diterbitkan. Banjarmasin: Program Studi Pendidikan Bahasa dan Sastra Indonesia Sekolah Tinggi Keguruan dan Ilmu Pendidikan.

Alkaf, J. 2017. Permasalahan Gender yang Terjadi dalam Novel Re: Karya Maman Suherman. Skripsi tidak diterbitkan. Banjarmasin: Program Studi Pendidikan Bahasa dan Sastra Indonesia Sekolah Tinggi Keguruan dan Ilmu Pendidikan. 
Endraswara, S. 2013. Metodologi Penelitian Sastra. Yogyakarta: Cencer for Academic Publishing Service.

Endraswara, S. 2008. Metode Penelitian Psikologi Sastra. Yogyakarta: MedPress (Anggota IKAPI).

Minderop, A. 2013. Psikologi Sastra. Jakarta: Yayasan Pustaka Obor Indonesia anggota IKAPI DKI Jakarta.

Ratna, N. K. 2011. Teori, Metode Dan Teknik Penelitian Sastra. Yogyakarta: PustakaPelajar.

Wijaya dan Shoim. 2014. Kritik Sosial Dalam Lirik Lagu Iwan Fals Periode Tahun 1980-1992. Jurnal tidak diterbitkan. Surabaya: Program Studi Pendidikan Bahasa dan Sastra Indonesia Universitas PGRI Adi Buana Surabaya. Diakses pada tanggal 10 Januari 2019 pukul 10:05 PM

Tim Penyusun. 2016. Pedoman Penulisan Skripsi. Banjarmasin: STKIP PGRI Banjarmasin.

ASKS XIII Dispora Kabupaten Tanah Laut. 2016. Membaca Sastra Mengikat Makna. Banjarbaru: Scripta Cendekia. 